\title{
Conventional and organic cropping systems at Suitia VI: Insect populations in barley
}

\author{
JUHA HELENIUS \\ Department of Agricultural and Forest Zoology, University of Helsinki, \\ SF-00710 Helsinki, Finland
}

\begin{abstract}
In 1988, insects were sampled from tillers and by pitfall trapping in a long-term field experiment consisting of plots of organic and conventional barley. The organic crops suffered from lack of nitrogen and from draught stress, and growth and development were retarded. The stand characteristics were suggested to be the major determinants of the fourfold higher densities of Rhopalosiphum padi (L.) (Hom., Aphididae) and the $50 \%$ lower densities of Frankliniella tenuicornis Uzel (Thys., Thripidae) in the conventional than in the organic barley. The $75 \%$ lower catch rate of Bembidion spp. (Col., Carabidae) in the conventional barley was attributed to lower activity resulting from the more closed canopy and more dense crop. However, the effect of an aphicide applied to the conventional crop was confounded with the true habitat effects. The densities of Coccinella septempunctata L. (Col., Coccinellidae) were almost three times higher in the conventional than in the organic barley, which in turn was attributed to the higher prey (aphid) densities.
\end{abstract}

Index words: Hordeum vulgare, Rhopalosiphum padi, Coccinellidae, Carabidae, Staphylinidae, Araneae, Frankliniella tenuicornis

\section{Introduction}

One of the major problems encountered in developing organic agriculture is how to avoid excessive pest damage to the crop plants, as pesticides are not allowed. The effects of cropping systems on insect populations have been dealt with in several experimental studies (e.g. Dritschilo \& WANner 1980, Wichtrup et al. 1985, Hokkanen \& Holopainen 1986, LetSCHERT 1986, Burn 1987, El-Titi \& LANDES 1988; see also Potts \& Vickerman 1974), many of which have concentrated on epigeal faunas, especially Carabidae (Col.). In this study, the focus was on populations of the main cereal pest, Rhopalosiphum padi (L.) (e.g. RAUTAPÄÄ 1976) and its predators in barley (Hordeum vulgare (L.)) in conventional and organic experimental systems. The object was to describe rather than explain the possible differences in aphid infestation and numbers of their epigeal polyphagous predators 
(e.g. Helenius 1990) between the systems. Sampling was confined to just one year, 1988, of the experiment, started already in 1981 (see HannukKala et al. 1990, in this issue).

\section{Material and methods}

Details of the experimental design are given by HannukKala et al. (1990), in this issue. The entomological sampling was done in the rotation $a$ in 1988, in which barley was grown in all the plots. The cultivar was Pokko $\mathrm{Hja}$. The sampling was confined to a $2 \mathrm{~m} \times 6 \mathrm{~m}$ area in the centre of each of the experimental plots. The treatments (cropping systems) nested with the cropping pattern (organic or conventional) are given in Table 1. Spraying with dimethoate, at a rate of $268 \mathrm{~g} / \mathrm{ha}$, was made in the conventionally grown plots on $3 \mathrm{rd}$ June, when the crop was at the two-leaf stage. There were no controls for the effects of spraying, which thus became confounded by other effects of the cropping pattern.

The populations of $R$. padi were monitored, from colonization to collapse, by sampling tillers of barley between 1st June and 29th June. Incidence counts (e.g. Еквом 1987) were made on 1st June and 7th or 8th June, and score estimation (see LowE 1984) was used on 15th June, 22nd June and 29th June. The sample size was 20 tillers per plot, except on 29 June, when the collapse of the populations could be confirmed visually. The total number of aphids was counted in situ. At the peak density, on 22nd June, the sampled tillers were pulled up gently, and the aphids located on the stem base (c.f. WIKTELIUS 1987) below the soil surface were included.

In order to monitor the activity abundance (c.f. Halsall \& Wratten 1988) of epigeal predators, three pitfall traps, with a diameter of $120 \mathrm{~mm}$, were placed in a row, at $2 \mathrm{~m}$ intervals in each plot. The medium was water with detergent added. The traps were emptied once a week from 25th May to 29th June. The numbers of carabids (Col., Carabidae), staphylinids (Col., Staphylinidae), spiders (Araneae), adults of Coccinella septempunctata $\mathrm{L}$. and coccinellid larvae (Col., Coccinellidae), and the total numbers of aphids in the catch were counted.

On 29th June two quadrates of $0.092 \mathrm{~m}^{2}$ per plot were sampled for absolute densities of coccinellid adults, larvae and pupae. On 11th July, 20 panicles per plot were sampled to determine the infestation level of Frankliniella tenuicornis (Uzel) (Thysanoptera, Thripidae). The adults and larvae of the thrips were flotated from the panicles by submerging the samples in water $\left(\mathrm{ca} .20^{\circ} \mathrm{C}\right.$ ) containing detergent for one day, after which the dead animals were decanted and counted. The dry matter weight of the panicles was determined.

Standard analysis of variance procedures were used for testing statistical significance of treatment effects. The model was described by HannukKala et al. (1990). The notation S.E.

Table 1. Treatments representing the different systems in the conventional and organic cropping. The treatments were nested within the cropping patterns. There were three blocks. For details, see HanNUKKALA et al. (1990).

\begin{tabular}{|c|c|c|}
\hline & Crop in 1988 & Preceding crop in 1987 \\
\hline \multicolumn{3}{|l|}{ Conventional: } \\
\hline 1. Monoculture & barley & barley \\
\hline 2. Cereal rotation & $"$ & $n$ \\
\hline 3. Diverse field crop rotation & $n$ & turnip rape \\
\hline 4. Ley rotation & $"$ & oats \\
\hline \multicolumn{3}{|l|}{ Organic: } \\
\hline 5. Composted green manure & barley + clover undersown & oats + faba bean mixed crop \\
\hline 6. Green manure & $"$ & $m$ \\
\hline 7. Composted slurry & barley & $"$ \\
\hline 8. Slurry & $"$ & $"$ \\
\hline
\end{tabular}


is used for standard errors of means, and these are given as mean \pm S.E.

\section{Results and discussion}

\section{R. padi in barley}

The conventional barley was colonized quicker by $R$. padi, i.e. the proportion of infested tillers grew faster, and the populations reached peak densities four times higher in this as compared to the organic barley (Table 2). The reasons for the obvious failure of the aphicide in controlling the aphids are not known. There were no significant differences in aphid densities between the systems in conventional cropping, or between the systems in organic cropping.

The mild infestation in organic cropping is evidently related to the fact that the growth of barley was very poor. The above-ground biomass of barley at about the time (4th July) of peak aphid density was only $18.9 \%$ of that in the conventional farming (KORVA \& VARIS 1990, in this issue). The canopies were not closed, and the growth stage was 31 (1st node visible; Totтman et al. 1979), while the canopies of the conventionally grown barley crops were closed, and the growth stage was 53 (onefourth of the ear emerged).
Nitrogen deficiency, which was especially pronounced early in the season during the aphid period and led to draught stress due to insufficient root growth, was obviously one of the major reasons for the poor performance of the organic barley (KorVA \& V ARIS 1990). The nitrogen content and metabolism in host plants plays an important role in the growth and development of herbivorous insects and their populations (MATTSON 1980), and it is realistic to assume that this nitrogen/host plant/herbivore relationship also contributed to the results presented here.

By the end of June, practically all aphids had disappeared from the crops; small colonies were encountered occasionally, most of which were in the organic barley. The rapid development and degeneration of the aphid populations was caused by exceptionally hot weather conditions combined with exceptionally high rates of colonization by alate migrants.

The numbers of aphids in pitfall traps were high (Table 3), confirming the finding of Sopp et al. (1987) and WiKTELIUS (1989) that cereal aphids are active on the soil surface. The 27 -fold greater catch in the conventional as opposed to the organic farming during the collapse period is best explained by the larger peak populations on stems combined with the

Table 2. Incidence (proportion of infested tillers) and mean density (numbers/tiller) of Rhopalosiphum padi and mean density of Frankliniella tenuicornis (numbers/panicle) in organic and conventional barley. ( \pm S.E.)

\begin{tabular}{lccccc}
\hline & & Date & Organic & Conventional & $p$ \\
\hline R. padi & incidence & $1 / 6$ & $0.1 \pm 0.03$ & $0.4 \pm 0.03$ & 0.04 \\
& & $7-8 / 6$ & $0.2 \pm 0.05$ & $0.4 \pm 0.05$ & 0.2 \\
& & $22 / 6$ & 1 & 1 & \\
\\
F. tenuicornis & mean & $22 / 6$ & $19.6 \pm 2.38$ & $88.42 \pm 15.98$ & 0.03 \\
& mean & $11 / 7$ & $28.7 \pm 2.23$ & $16.45 \pm 1.26$ & 0.02 \\
\hline
\end{tabular}

Table 3. Mean catch of Rhopalosiphum padi in pitfall traps (numbers/trap/day) in organic and conventional barley. ( \pm S.E.)

\begin{tabular}{lcrc}
\hline Trapping period & Organic & Conventional & $p$ \\
\hline $15-22$ June & $15.0 \pm 1.89$ & $269.3 \pm 19.06$ & $<0.001$ \\
$22-29$ June & $38.1 \pm 6.05$ & $1025.6 \pm 129.32$ & 0.05 \\
\hline
\end{tabular}


higher density of stems (KORVA \& VARIS 1990) in the conventional farming, which resulted in a difference in densities per unit area that was relatively larger than the difference in densites per stem (tiller).

\section{Epigeal predators}

The pitfall catches did not reveal many statistically significant differences in the activity abundances of epigeal predators between organic and conventional cropping (Table 4). The catch rate of Bembidion spp. was four times higher in the organic than in the conventional barley. As with most of the other taxa, the exception being spiders, the catch rates were highest during the first week of trapping. However, in the case of Bembidion spp. the first week's catch was 1.5 times higher in the organic than in the conventional barley, but thereafter the ratio increased to 16.3 $(p<0.001$, chi-square test). This was not observed with the other taxa. One explanation for the sharp reduction in catch rate after the first week in the conventional barley would be an increased mortality or decreased activity because of the spraying with dimethoate.

An alternative explanation is that the reduction in the catch rate in the conventional barley was caused by some changes in the crop habitat; the two types of habitat, conventional and organic, became increasingly different over the course of time. The habitat charac- teristics affecting activity and diffuse movement patterns, rather than the population density of the Bembidion spp., such as lower prey density, lower tiller density and more sunexposed soil surface in the organic farming, may have contributed most to the difference between conventional and organic barley in the catch rates of the beetles. In the plot experiments, the plot boundaries apparently were not the population boundaries.

It has been suggested that Bembidion are important predators of $R$. padi early in the season, and that they may even prevent outbreaks if the immigration rate of aphid colonists is moderate (Еквом \& WiKTelius 1985, Chiverton 1987, Helenius 1990). In the study year, however, the initial infestation was high, and it is doubtful that the Bembidion spp. could have had anything but a minor contribution to the lower peak densities of aphids in the organic as compared to the conventional barley.

Within organic cropping, the catch rate of Bembidion spp. in the system given uncomposted green manure (treatment 6 ) was significantly lower than in the other systems ( $p=$ 0.005 ) (Fig. 1). The reasons for this can only be speculated; it seems as if catches were influenced by both the type and the management of the organic fertiliser.

There was an indication of a higher catch rate of Pterostichus spp. in the conventional than in the organic barley. The difference per-

Table 4. Mean catch of carabids, staphylinids, spiders, Coccinella septempunctata and coccinellid larvae in pitfall traps (numbers/trap/day) during 25th May -29 th June in organic and conventional barley. ( \pm S.E.)

\begin{tabular}{llll}
\hline & Organic & Conventional & $p$ \\
\hline Carabidae & & & 0.005 \\
$\quad$ Bembidion spp. & $0.17 \pm 0.018$ & $0.04 \pm 0.012$ & 0.3 \\
$\quad$ Trechus spp. & $0.05 \pm 0.011$ & $0.09 \pm 0.010$ & 0.6 \\
Clivina fossor (L.) & $0.01 \pm 0.004$ & $0.03 \pm 0.011$ & 0.8 \\
$\quad$ Harpalus spp. & $0.02 \pm 0.003$ & $0.02 \pm 0.003$ & 0.06 \\
$\quad$ Pterostichus spp. & $0.07 \pm 0.012$ & $0.16 \pm 0.030$ & 0.1 \\
$\quad$ Others & $0.01 \pm 0.003$ & $0.02 \pm 0.003$ & 0.4 \\
Staphylinidae & $0.26 \pm 0.019$ & $0.28 \pm 0.038$ & 0.7 \\
Araneae & $0.47 \pm 0.048$ & $0.55 \pm 0.159$ & 0.2 \\
C. septempunctata adults & $0.05 \pm 0.008$ & $0.12 \pm 0.024$ & 0.09 \\
Coccinellid larvae & $0.06 \pm 0.009$ & $0.24 \pm 0.045$ & \\
\hline
\end{tabular}


sisted after the application of dimethoate. The result may be explained by habitat preferences, as in the case of Bembidion spp., but aggregation to the plots of high prey density is also possible (c.f. Bryan \& Wratten 1984). The Pterostichus are large, very mobile carabids whose peak activity period overlaps with the peak and collapse phases of $R$. padi (e.g. Helenius 1990).

In the conventional cropping, the catch rate of staphylinids was significantly higher $(0.44 \pm 0.042$ specimens/trap/day) in the ley rotation (treatment 4 ) than in the monoculture $(0.20 \pm 0.053$, treatment 1$)$. The lowest mean catch was in the organic cropping in the plots manured with uncomposted slurry $(0.20 \pm 0.014$, treatment 8$)$. Many species of staphylinids are saprophages; thus, the numbers should be related to amount of decomposing material in soil.

\section{Coccinellids}

The sampling for coccinellid densities was done just after the collapse of the aphid populations. According to assessment based on visual observations, the coccinellid densities at that time were at their maximum. In the conventional cropping, the mean density of adult $C$. septempunctata was 48.9 per $\mathrm{m}^{2}$, but in the organic cropping, only 18.1 per $\mathrm{m}^{2}$ $(p<0.05$, t-test). The mean densities of coccinellid larvae were 21.7 and 3.6 per $\mathrm{m}^{2}$, respectively. Altogether only nine pupae were sampled, all in the conventionally grown barley. The most obvious explanation for the pattern was aggregation of the predators to the patches of high prey density, i.e. plots of conventional barley.

\section{Thrips}

The results concerning $F$. tenuicornis were from just one sampling, and do not allow definite conclusions. However, at the time of sampling, the population densities of $F$. tenuicornis were almost twice as high in the ears of barley in the organic cropping than in the

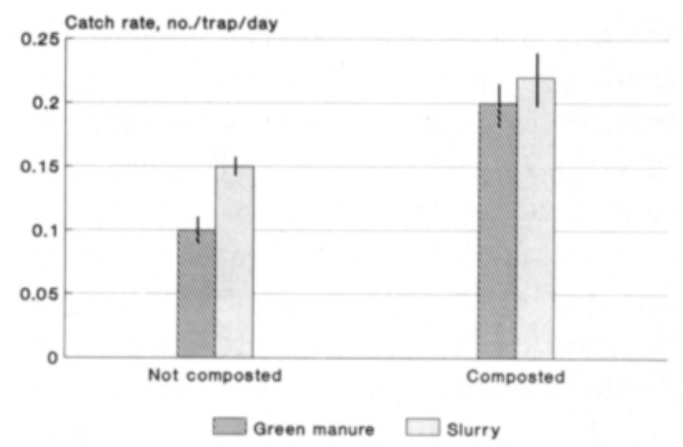

Fig. 1. Catch rates (number of specimens/trap/day) of Bembidion spp. in pitfall trapping in the organic barley. (Vertical bars: \pm S.E.)

conventional cropping (Table 2). Relative to the biomass of panicles, the infestation was even more severe in the organic barley, as the ears weighed only $33.3 \%$ of those in the conventional barley ( $p=0.002)$ (Fig. 2). At sampling, the ear emergence was only $70 \%$ in the organic barley, whereas in the conventional barley it was $100 \%$. Host plant and habitat characteristics may explain the difference between the cropping alternatives. F. tenuicornis causes total and partial white heads in cereals (Reuter 1901, Kanervo 1950), but the damage was not assessed in this study.

The findings of this study cannot be generalized to make a comparison of organic vs. conventional cropping. They are useful in

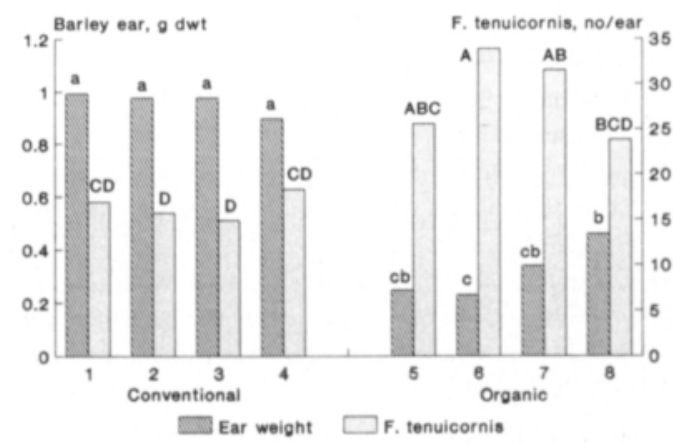

Fig. 2. The means of ear weight of barley and mean densities of the thrips $F$. tenuicornis (adults and larvae) on the ears on 29 th June. The numbers $1-8$ on the $x$-axis denote the treatments as explained in Table 1. Statistically significant differences are indicated by letters above the bars (HSD-tests). 
showing how the host plant and stand characteristics, varying along with the input levels, may be key factors in determining the numbers of pests and their natural enemies. Concerning the most mobile arthropods, plot experiments allow for choice between the habitat patches. For example, in order to determine the effects of agronomical practices on carabids, comparisons between entire fields or, preferably, farms should be made in the long term.

Acknowledgements. I would like to thank Prof. AnnaLiisa Varis for the initiative to perform this study and, together with Jukka Korva, Visa Nuutinen and the other members of the team for commenting on the manuscript. I wish to thank Markku Pulkkinen for the taxonomical work, and Sevastiana Ruusamo, M.A., for linguistic revision of the manuscript.

\section{References}

Bryan, K.M. \& WRATTEN, S.D. 1984. The responses of polyphagous predators to prey spatial heterogeneity: aggregation by carabid and staphylinid beetles to their cereal aphid prey. Ecol. Entomol. 9: 251-259.

Burn, A.J. 1987. The Boxworth project. Bull. SROP/WPRS Bull. $1987 / X / 1$, p. 216-217. (WG "Integrated control of cereal pests")

Chiverton, P.A. 1987. Predation of Rhopalosiphum padi (Hom.: Aphididae) by polyphagous predatory arthropods during the aphids' pre-peak period in spring barley. Ann. Appl. Biol. 111: 257-269.

Dritschilo, W. \& WanNer, D. 1980. Ground beetle abundance in organic and conventional corn fields. Environ. Entomol. 9: 629-631.

Еквом, B.S. 1987. Incidence counts for estimating densities of Rhopalosiphum padi (Homoptera: Aphididae). J. Econ. Ent. 80: 933-935.

Еквом, B.S. \& Wiктеlıus, S. 1985. Polyphagous arthropod predators in cereal crops in central Sweden, 1979-1982. Z. angew. Entomol. 99: 433-442.

El-Titi, A. \& Landes, H. 1988. The integrated farming system of Lautenbach: a practical contribution towards sustainable agriculture in Europe. Proc. Conf. Sustainable Agriculture, Ohio 23-27 Sept., 1988. Manuscript.

Halsall, N.B. \& Wratten, S.D. 1988. The efficiency of pitfall trapping for polyphagous predatory Carabidae. Ecol. Entomol. 13: 293-299.

Helenius, J. 1990. Effect of epigeal predators on infestation by the aphid Rhopalosiphum padi and on grain yield of oats in monocrops and mixed intercrops. Ent. Exp. Appl. 54: 225-236.

Hokkanen, H. \& Holopainen, J.K. 1986. Carabid species and activity densities in biologically and conventionally managed cabbage fields. J. Appl. Ent. 102: 353-363.

Kanervo, V. 1950. Frankliniella tenuicornis Uzel (Thysanoptera) als intrafloraler Schädling an Gerste. 8th Int. Congr. Ent., Proc. p. 647-653. Stockholm.
Hannukkala, A.O., Korva, J. \& Tapio, E. 1990. Conventional and organic cropping systems at Suitia I: Experimental design and summaries. J. Agric. Sci. Finl. 62: 295-307.

Korva, J. \& VARIS, E. 1990. Conventional and organic cropping systems at Suitia II: Crop growth and yields. J. Agric. Sci. Finl. 62: 309-319.

LetSCHERT, D. 1986. Untersuchungen zur Arthropodenund Annelidenfauna von Weizen- und Zuckerrüebenfeldern in einem konventionellen und einem biologisch-dynamischen Anbau. Z. angew. Zool. 73: 93113.

LowE, H.J.B. 1984. The assessment of populations of the aphid Sitobion avenae in field trials. J. Agric. Sci. 102: $487-497$.

MAtrson, W.J. Jr. 1980. Herbivory in relation to plant nitrogen content. Ann. Rev. Ecol. Syst. 11: 119-161.

Potts, G.R. \& Vickerman, G.P. 1974. Studies on the cereal ecosystem. Adv. Ecol. Res. 8: 107-197.

RAutAPÃA, J. 1976. Population dynamics of cereal aphids and method of predicting population trends. Ann. Agric. Fenn. 15: 272-293.

Reuter, E. 1901. Physopus tenuicornis Uzel als Erzeuger totaler Weissährigkeit bei Hafer. Medd. Soc. Fauna et Flora Fenn. 27: 115-120.

Sopp, P.I., Sunderland, K.D. \& CoOmbes, D.S. 1987. Observations on the number of cereal aphids on the soil in relation to aphid density in winter wheat. Ann. Appl. Biol. 111: 53-57.

Tottman, D.R., MaKepeace, R.J. \& Broad, H. 1979. An explanation of the decimal code for the growth stages of cereals, with illustrations. Ann. Appl. Biol. 93: $221-234$.

Wichtrup, L.G., Steiner, H. \& Wipperfurth, T. 1985. Der Einfluss von Klee als Untersaat auf die Populationsdynamik von Blattläusen (Homoptera, Aphididae) und epigäischen Arthropoden bei Winterweizen im Lautenbach-Projekt. Mitt. Deutschen Gesellschaft allgem. angew. Ent. 4: 430-432. 
WIKTELIUS, S. 1987. Distribution of Rhopalosiphum padi (Homoptera: Aphididae) on spring barley plants. Ann. Appl. Biol. 110: 1-7.

- 1989. Migration of apterous Rhopalosiphum padi.
Bull. SROP/WPRS Bull. 1989/XII/1, p. 1-6. (WG

"Integrated control of cereal pests")

Ms received April 2, 1990

\section{SELOSTUS}

\section{Suitian viljelyjärjestelmät VI: Hyönteispopulaatiot ohrakasvustoissa}

\author{
Juha Helenius \\ Helsingin yliopisto, maatalous- ja \\ metsadelaintieteen laitos
}

Suitian koetilalla Uudellamaalla järjestetyssả kenttäkokeessa vertailtiin vuosina $1982-1988$ kahdeksaa luonnonmukaista ja tavanomaista viljelyjärjestelmäă. Viimeisenă koevuonna 1988 tehtiin hyönteishavainnot kaikissa kierroissa mukana olleesta Pokko Hja -ohrasta. Tuomikirvojen Rhopalosiphum padi runsaus arvioitiin viikoittaisin verso-otannoin. Epigeeisen petoniveljalkaislajiston aktiivisuusrunsautta selvitettiin kuoppa-ansapyynnillä. Leppăpirkkojen Coccinella septempunctata runsaudesta tehtiin kesăkuun lopulla năytealaotanta, ja heinäkuun puolivălissă otettiin tăhkănäytteet kauraripsiäisen Frankliniella tenuicornis runsauden arvioimiseksi.

Vuosi oli poikkeuksellinen ns. kirvavuosi, ja kasvustojen alkusaastunta oli sekả kotimaisten että kaukolevintänä maahan saapuneiden kolonistien runsauden vuoksi voimakas. Dimetoaatilla suoritetusta torjuntaruiskutuksesta huolimatta tuomikirvan populaatioiden runsaushuippu tavanomaisessa viljelyssă oli keskimäărin $88 \mathrm{yksi}$ lö/verso, mutta luonnonmukaisessa viljelyssă, jossa torjuntaa ei tehty, huippu oli vain neljănnes tästă, keskimaaãrin $20 \mathrm{yksiloă/verso.} \mathrm{Ero} \mathrm{selittyi} \mathrm{ensisijaisesti} \mathrm{sillă,} \mathrm{ettả}$ luonnonmukaisten järjestelmien ohrakasvustot kärsivăt typen ja veden puutteesta juuri kirvapopulaatioiden eksponentiaalisen kasvuvaiheen aikana: tuomikirvat eivăt kyenneet tehokkaasti lisääntymään heikosti kasvavissa luonnonmukaisissa ruuduissa. Tavanomaisessa viljelyssă tehdyn torjuntaruiskutuksen huono teho johtui ilmeisimmin siitä, ettă tehoaine ei tavoittanut ruiskutusajankohtana pääosin juurenniskaan asettuneita kirvoja.
Kauraripsiäiset olivat noin kaksi kertaa runsaampia luonnonmukaisesti kuin tavanomaisesti viljellyn ohran tăhkissă. Fytomassayksikkőă kohden ero oli vielă suurempi, sillă luonnonmukaisesti viljellyn ohran tăhkăpaino otanta-ajankohtana oli vain $33 \%$ tavanomaisesti viljellyn ohran tảhkäpainosta.

Kuoppa-ansapyynnit eivăt osoittaneet suuria ruutujen vălisiă eroja maakiitäjäisten (Coleoptera, Carabidae), lyhytsiipisten (Col., Staphylinidae) tai hämähäkkien (Araneae) esiintymisessä. Hyrräkiitäjăisten Bembidion spp. aktiivisuusrunsaus oli $25 \%$ alempi tavanomaisesti kuin luonnonmukaisesti viljellyissä kasvustoissa. Mahdollisia selittäviả tekijöită olivat habitaattieroavuudet (tavanomainen ohrakasvusto oli ns. normaali, mutta luonnonmukainen oli harva, matalakasvuinen ja sulkeutumaton) sekä eroavuudet pảảasiallisen saaliseläimen, tuomikirvan määrissä. Voimakas kirvasaastunta keräsi tavanomaiseen ohraan leppäpirkkoja lähes kolme kertaa suuremman mäărăn kuin mită tavattiin luonnonmukaisesti viljellystă ohrasta.

Tutkimusvuonna olivat hyönteisten kannalta merkittävimmät erot tavanomaisesti ja luonnonmukaisesti viljeltyjen kasvustojen vălillă ensisijaisesti habitaatin rakenteeseen sekä isăntăkasvin, ohran vesi- ja typpitaloudesta riippuneeseen laatuun liittyviä. Tuloksia ei voida yleistảă toisenlaisiin kasvuoloihin tai kokonaisten tilojen mittakaavaan LUOMU- ja tavanomaisen viljelyn vertailussa. 